IZA DP No. 8359

Changes in Bargaining Status and Intra-Plant

Wage Dispersion in Germany:

A Case of (Almost) Plus Ça Change?

John T. Addison

Arnd Kölling

Paulino Teixeira

July 2014 


\title{
Changes in Bargaining Status and Intra-Plant Wage Dispersion in Germany: A Case of (Almost) Plus Ça Change?
}

\author{
John T. Addison \\ University of South Carolina, University of Durham and IZA \\ Arnd Kölling \\ Berlin School of Economics and Law \\ Paulino Teixeira \\ University of Coimbra/GEMF and IZA \\ Discussion Paper No. 8359 \\ July 2014 \\ IZA \\ P.O. Box 7240 \\ 53072 Bonn \\ Germany \\ Phone: +49-228-3894-0 \\ Fax: +49-228-3894-180 \\ E-mail: iza@iza.org
}

Any opinions expressed here are those of the author(s) and not those of IZA. Research published in this series may include views on policy, but the institute itself takes no institutional policy positions. The IZA research network is committed to the IZA Guiding Principles of Research Integrity.

The Institute for the Study of Labor (IZA) in Bonn is a local and virtual international research center and a place of communication between science, politics and business. IZA is an independent nonprofit organization supported by Deutsche Post Foundation. The center is associated with the University of Bonn and offers a stimulating research environment through its international network, workshops and conferences, data service, project support, research visits and doctoral program. IZA engages in (i) original and internationally competitive research in all fields of labor economics, (ii) development of policy concepts, and (iii) dissemination of research results and concepts to the interested public.

IZA Discussion Papers often represent preliminary work and are circulated to encourage discussion. Citation of such a paper should account for its provisional character. A revised version may be available directly from the author. 


\title{
ABSTRACT
}

\section{Changes in Bargaining Status and Intra-Plant Wage Dispersion in Germany: A Case of (Almost) Plus Ça Change?}

\begin{abstract}
Recent studies have pointed to the association between declining collective bargaining coverage and rising overall wage inequality. This association holds more or less across-theboard, at least for broad swathes of recent history. That said, the exact contribution of deununionization is a matter of debate, perhaps no more so than in Germany, our case study. The present paper takes a less conventional approach to this particular source of rising inequality by examining intra-plant wage dispersion in the wake of establishments either exiting from or entering into collective agreements. Several measures of inequality are constructed for German establishments over the twelve-year period 1996-2008, an interval of continuously declining union representation. Using linked employer-employee data, our estimation strategy hinges upon the identification of comparable groups of establishments and on both instantaneous and medium- to long-term changes in the wage structure. A modest widening effect on dispersion of exiting from a sectoral agreement is detected in the data once we effect a comparison across observationally-equivalent individuals. The converse does not apply in respect of joiners. The scale of the former effect casts doubt on some of the more exaggerated claims of the importance of deunionization to wage inequality and the resurgence of Germany more generally.
\end{abstract}

JEL Classification: J31, J51, J53

Keywords: Germany, collective bargaining, deunionization, intra-plant wage inequality, sectoral agreement exits and accessions

Corresponding author:

John T. Addison

Department of Economics

Moore School of Business

1014 Greene Street

University of South Carolina

Columbia, SC 229208

USA

E-mail: ecceaddi@moore.sc.edu 


\section{Introduction}

Unions are typically associated with lower earnings dispersion or inequality. This is because of two main reasons. First, unions lower skill differentials in union establishments - even if, as a practical matter, rather little work has focused on union effects at plant level (major exceptions are Freeman, 1982, and Lewis, 1986). Second they standardize pay among workers with similar measured attributes. These effects dominate the opposing influence of the positive union wage gap. For its part, the decline in unionization has been allied to rising wage inequality, with much attention being accorded the decades of the 1980s and 1990s - intervals characterized by material declines in union density and often sharply rising inequality.

Despite the strong inverse correlation between unions and inequality, there are several important caveats. One is technical: the fact that union policies affect sorting in the labor market; specifically, positive sorting on low measured skill and negative sorting on high-measured skill. That is to say, union workers with low measured skills have higher unobserved skills than nonunion workers in the same group (reflecting a binding demand-side constraint), while those in the upper skill groups have lower unobserved skills (here a supply-side constraint). The result is an exaggeration of union narrowing tendencies unless controlled for (see Card, 1996; Rios-Avila and Hirsch, 2014). And, as Hirsch $(2004,256)$ notes, there are also issues of reverse causation since unions are likely to be more successful in organizing campaigns where worker skills (and tastes) are homogeneous. Homogeneous worker skills and preferences make it more likely that unions will be successful in representation elections. Worker preferences may also play an important role in explaining particular instances where union decline seemingly accounts for little of the rise in inequality (e.g. for the U.K., 1983-1995, see Addison, Bailey, and Siebert, 2007). Indeed, there are more general indications that since the mid-1990s union decline has been less closely associated with rising earnings inequality than heretofore. In a recent cross country analysis, Pontusson (2013) has argued that unionization is of diminishing importance due to changes in the position of union members in the income distribution. The reasoning is that the average union member has become better off as union membership has declined, and union members have become less supportive of wage solidarity (and redistributive government policies as well).

Notwithstanding these caveats, the time seems ripe to investigate German wage inequality for a number of reasons. First, the decline in German unions has 
continued apace in recent years, after the decline in many other nations has leveled off. Second, in addition to the growth of individual bargaining there has also occurred increasing flexibility in collective bargaining with the decentralization of sectoral agreements, as indexed by the contractual innovations of opening clauses and socalled pacts for employment and competitiveness (analogous to 'partnership agreements' in the U.K., a more thorough-going form of concession bargaining). Third, the combination of both developments has been allied not only to falling real wages and rising wage inequality - widely observed in the German literature (see section II below) - but also, and more controversially, as providing the key to that nation's resurgent economy during and subsequent to the Great Recession. In particular, Dustmann et al. (2014) have argued that the decline in union power (and the strengthened role of works councils in wage determination) rather than the labor market reforms beginning in 2003 under the Hartz Plan (and especially Hartz IV) was the prime mechanism restoring German competitiveness.

Since these authors also argue that their results are consistent with the increased importance of firm level differences in wages (section II), it seems of no small interest to examine the course of intra-plant wage differentials attendant upon a change in bargaining status, especially at a time of profound changes in collective bargaining coverage. We recognize that this is only a part of the picture since a fuller analysis would recognize the role internal flexibility (via opening clauses and company pacts). Unfortunately, data on the latter is too limited to permit its incorporation within the time frame of the present study, although such contractual innovations may of course have a bearing on the magnitude of the changes in wage dispersion uncovered here. ${ }^{1}$

To anticipate our findings, we report evidence of a significant but somewhat modest effect of switching bargaining regimes on establishment wage inequality. Specifically, exiting a collective agreement, though not joining one, is associated with increased wage inequality. Accordingly, while our data confirm that since the mid1990s there has been a substantive increase in both overall (worker) and withinestablishment wage dispersion, there is insufficient evidence to support the claim that this outcome is produced by shifts in collective bargaining. To repeat, this still leaves open the role of contractual innovations on which more evidence is urgently required. In the interstices, however, the role of one popular explanation - deunionization might need to be downplayed. 


\section{Previous Research on Earnings Dispersion in Germany}

German studies have indicated that rising wage inequality in recent years is not a phenomenon confined to the Anglo-Saxon countries. What distinguishes Germany is that the increase came later, or better put came later at the lower tail of the wage distribution. The best-known study (covering western Germany) is that of Dustmann, Ludsteck, and Schönberg (2009), using the IABS, a 2 percent random sample of social security records, 1975-2004, and the LIAB, a linked employer-employee dataset. The authors report that wage inequality increased over these three decades - during the 1980s at the top of the distribution and during the 1990s at the bottom end as well. The authors explore several explanations for the increase in wage inequality. Focusing here on the 1990s, the authors argue that episodic events - rather than changes in workforce composition and the polarization of work (i.e. demand shifts favoring the high-skilled relative to the low-skilled) - explain the widening of the wage distribution at the bottom. Episodic events include changes in labor market institutions and labor supply shocks.

In particular, the decline in union coverage 1995-2004 (12 percentage points in the case of sectoral agreements) is found to contribute significantly to the widening in dispersion over these years. Using the kernel reweighting decomposition procedure of Dinardo, Fortin, and Lemieux (1996) to recover the counterfactual wage distribution that would have obtained had workforce composition/unionization rates remained unchanged, it is estimated that workers throughout the distribution would have enjoyed higher wage growth over the period. And this higher wage growth would have been most pronounced at the lower end of the wage distribution. Specifically, between 1995 and 2004 the overall 80-50 wage gap rose by $0.068 \log$ points whereas the increase in this upper tail inequality would have been 0.059 points had unionization coverage remained at its 1995 level. This reduction of 13 percent is dwarfed at the lower end of the distribution, however, where deunionization can account for 28 percent of the increase in the overall 50-15 wage gap. Production function analysis is used to assess the contribution of another episodic event to wage differentials; namely, fluctuations in relative labor supply. Supply shocks, associated with the infusion of low-skilled ethnic German and East Germans, are reported to have contributed very significantly to trends in the wage differential between medium and low skilled workers. Episodic factors in the form of institutional change and changes in relative supply largely fail to explain trends in the differential between high 
skilled and medium skilled workers. Rather, the source of widening at the top of the distribution is attributed to technological change.

A somewhat more differentiated picture is presented by Antonczyk, Fitzenberger, and Sommerfeld (2010) in a recent analysis using the 2001 and 2006 repeated cross sections of the German Structure of Earnings Survey (GSES). ${ }^{2}$ The study investigates the contribution of firm effects, bargaining effects (i.e. deunionization) and personal characteristics to rising inequality over a period in which unionization is estimated to have declined by between 16.5 percentage points in the case of males and rather more than that for females. The gender wage gap is a central focus of the inquiry but one that may be omitted here since reduced collective bargaining plays almost no role here in the gender wage gap. The study uses a set of linear quantile regression estimates to analyze the effects of workplace related effects and personal characteristics, and estimates a sequence of counterfactual wage distributions. The upshot of these procedures is that while the sharp decline in collective bargaining contributes to the material rise in earnings inequality - driven by real wage increases at the top of the wage distribution and real wage losses below the median - it is altogether less important than firm effects and much smaller than estimated by Dustmann, Ludsteck, and Schönberg (2009). ${ }^{3}$ Firm coefficient effects (largely driven by sector affiliation) dominate both in overall terms and especially at the bottom of the wage distribution. (For their part, personal characteristics, if not their coefficients, have changed in a way that serves to reduce wage inequality.)

Greater firm heterogeneity is also identified in another very recent study by Card, Heining, and Kline (2013) in an application of the Abowd, Kramarz, and Margolis (1999) model, using the IAB Integrated Employment Biographies (IEB) dataset for the period 1985-2009. The authors divide their sample period into four overlapping intervals and fit separate linear models to each with additive person and establishment fixed effects, namely the component of individual pay that is portable across jobs and that part which is a pay premium offered by different employers. It is reported that the model provides a good approximation of the wage structure and explains nearly all of the steep rise in wage inequality over the sample period. Specifically, increasing dispersion is attributed in large part to rising heterogeneity between workers and rising dispersion in the wage premiums of different establishments. Heightened assortativeness in the assignment of workers to establishments, captured by the correlation between the worker and establishment fixed effects, also plays a ma- 
terial role, so that individuals expected to earn more at any job are increasingly located in establishments offering above-average wages to all employees. Thus, for example, a variance decomposition exercise establishes that, between the first and last intervals, the variance of the person effect explains roughly 40 percent of the total increase in the variance in wages while the corresponding variance of the establishment effect accounts for another 25 percent. For its part, the contribution of assortative matching - the increase in the covariance term - contributed a further 34 percent. $^{4}$

Dustmann et al. $(2013,181)$ argue that the decentralization of the wage setting process - pure decentralization as manifested in bargaining between firms and their workers individually and the decentralization associated with contractual innovation in sectoral agreements - is consistent with the above findings that the rise in firm-level differences contribute strongly to the rise in wage inequality. ${ }^{5}$ But they do not examine the consequences of changes in bargaining structure over their sample period in any detail. Rather, they contrast observed wage growth 1995-2008 with the counterfactual growth that would have occurred had union coverage maintained its beginning-period value, again using the reweighting approach of Dinardo, Fortin and Lemieux (1996). As in Dustmann, Ludsteck and Schönberg (2009, 862), this exercise suggests that wages would otherwise have been higher across the board but particularly at the lower end of the distribution, albeit subject to the caveat that this procedure does not establish causality. Dustmann et al. also provide descriptive data on wage growth for three percentiles of the wage distribution in covered and uncovered sectors. On the basis of both pieces of evidence, they conclude that the rise in overall inequality between 1995 and 2008 is produced by three factors: " $\ldots$ the shift of workers from the covered sector to the uncovered sector (which led ... to an increase in lower tail inequality), the increase in inequality in the covered sector, and the increase in inequality at the top of the wage distribution in the uncovered sector" (Dustmann et al., 2009, 179). They proceed to attribute changes in wage inequality within the covered sector to the decentralization of sectoral bargaining. Decentralization is equated with opening clauses, although no independent analysis of these contractual innovations is offered.

It follows that the German evidence is decidedly mixed once one proceeds beyond the simple correlation of rising wage inequality and falling union coverage (and density). That the contribution of unionism is unclear is not really a question of the 
now accepted small impact of coverage on average wages (e.g. Addison et al., 2014) since most studies also indicate that unions are associated with a narrowing of the wage distribution (see, inter al., Gerlach and Stephan, 2002, 2006a, 2006b; Bechtel, Mödinger, and Strotmann, 2004; Kohn and Lembcke, 2007, Fitzenberger, Kohn, and Lembcke, 2013). That said, attempts to account for worker and firm heterogeneity point to very different results. Thus, Antonczyk (2010) who attempts to tackle the endogeneity of sectoral bargaining by using novel instrumental variables finds that coverage, while having no effect on the wage gap, lowers the conditional standard deviation of log wages by 26 percent. On the other hand, in a study also using linked employer-employee data, Guertzgen (2014) argues that the flattening of the wage structure associated with collection bargaining is a chimera produced by selectivity bias; with workers with low levels of observed skills tending to be positively selected and workers with higher levels of observed skills tending to be negatively selected into covered firms. Next, as we have learned from the studies examined in this section that seek to link union decline and wage dispersion directly, there is no single valued expectation of the consequences of deunionization. Even if the results point to some widening, the magnitudes are uncertain while unsettled causality issues dog decomposition exercises.

So we consider the time ripe to examine the consequences of changes in union coverage more directly by investigating the effects of joining/ leaving a collective agreement on the wage distribution of the establishment in question. We again note that this is only part of the story, most obviously because data considerations rule out consideration of the effect of contract flexibility which may yet turn out to be a more potent source of widening than changing (and, in particular, leaving) a collective agreement.

\section{Study Design}

Our study aims to analyze the impact of collective bargaining status on firm wage dispersion. However, since an establishment cannot be both 'covered' and 'uncovered,' a proper identification strategy of the causal effect requires the construction of a relevant comparator; that is, a group of establishments without a collective agreement that resemble or replicate the group of establishments with a collective agreement. 
To solve this 'fundamental evaluation problem,' the Roy-Rubin model or the 'model of potential outcomes' is usually applied (see Roy, 1951; Rubin, 1974). In practice, with cross-section data and letting $X$ capture all the relevant (observable) characteristics, the method amounts to assuming the conditional independence assumption' (CIA). Specifically,

$$
E\left(Y_{0} \mid D=1, X\right)=E\left(Y_{0} \mid D=0, X\right) \text {, }
$$

where $Y_{0}$ is the outcome for the untreated units and $D$ is the indicator of participation (i.e. $D=1$ for the treated and $D=0$ for the untreated). Ideally, the construction should be such that treated and untreated establishments are identical, differing only in their collective bargaining status. Under this assumption, the average treatment effect on the treated, $\gamma$, will be given by $\gamma=E\left(Y_{1}-Y_{0}\right)$, where $\mathrm{Y}_{1}$ denotes the outcome for the treated units.

Again, selection into the treatment is not likely to be exogenous. In other words, even after controlling for observables $X$, the control group of, say, uncovered establishments is unlikely to be entirely comparable to the group of covered establishments; selection into treatment/non-treatment being a result of unobserved (and distinct) traits that make the two groups actually dissimilar or incomparable. One way to deal with this problem is to use longitudinal data and generate first differences (between, say, $t_{0}$ and $t_{1}$ ), under the assumption that unobserved traits are time invariant. In combination with matching, this approach results in a (conditional) differencein-differences method yielding the average treatment effect (average treatment on the treated)

$$
\gamma=E\left(Y_{1 t_{1}}-Y_{1 t_{0}}\right)-E\left(Y_{0 t_{1}}-Y_{0 t_{0}}\right) \text {. }
$$

In this case, the relevant difference-in-differences identifying assumption is given by

$$
E\left(Y_{0 t_{1}}-Y_{0 t_{0}} \mid D=1, P(X)\right)=E\left(Y_{0 t_{1}}-Y_{0 t_{0}} \mid D=0, P(X)\right),
$$

where $P(X)$ denotes the propensity score or the probability of an establishment being treated, given $X$.

There are several matching methods available. One possible approach would be to use a one-to-one matching, in which case every treated unit is compared with just one untreated unit. Kernel matching is another possible route, one that assigns a positive weight to units of the control group whose propensity score lies within the estimated influence range around a participant. In this case, for an establishment $j$ outside the influence range, we have $w_{j}=0$, with the distribution of $w_{j}$ determined by 
a kernel density function. However, as described below, our preferred approach is to use radius matching, which amounts to assuming that each treated unit can be compared with a variety of untreated units located within a defined distance, with each unit of the control group entering with a certain weight, $w_{j}$, depending on a given criterion to yield a slightly different causal effect, that is,

$$
\gamma=E\left(Y_{1 t_{1}}-Y_{1 t_{0}}\right)-E\left(w_{j}\left(Y_{0 t_{1}}-Y_{0 t_{0}}\right)\right) \text {. }
$$

Regarding the outcome measure, our chief indicator is the (degree of) intraestablishment wage dispersion, given by the conditional wage differential, $\sigma_{j t}$ (after Winter-Ebmer and Zweimüller, 1999). Given that worker wages are top-censored (see below), the computations are based on censored regressions. For any given year $t$ and establishment $j$, our method amounts to conducting a censored regression of the daily worker (log) wage, $\ln W_{i j t}$, on a set of observables, $X_{i j t}$, and then using the corresponding standard error of the regression (or $\sigma_{j t}$ ) - one for each firm and year - as our selected measure of inequality in establishment $j$. Our conjecture then is that the 'adjusted' wage dispersion or residual inequality (that is, the wage dispersion of 'observationally equal' individuals) will depend on collective bargaining presence. In particular, in our conditional difference-in-differences approach this magnitude will be captured by the change in residual inequality observed in the group of collective agreement leavers (joiners), net of the corresponding change in the control group of always members (never members).

We will also use the $90^{\text {th }}, 50^{\text {th }}$, and $10^{\text {th }}$ percentiles of the log wage residuals obtained from establishment-level wage regressions to compute the corresponding $90^{\text {th }}-10^{\text {th }}$ and $50^{\text {th }}-10^{\text {th }}$ (adjusted) wage gaps. To clarify our procedure, let us assume, for a given year $t$ and establishment $j$, a standard Mincerian worker earnings equation of the form

$$
\ln W_{i j t}=X_{i j t} \beta+e_{i j t}
$$

where $X_{i j t}$ denotes observable characteristics and $e_{i j t}=\varepsilon_{j}+\alpha_{i}+\varsigma_{i j t}$ is a composite error term that includes unobserved worker and establishment traits, $\alpha_{i}$ and $\varepsilon_{j}$, respectively, together with an idiosyncratic term, $\varsigma_{i j t}$.

Defining the log wage residual as $w_{i j t}=\ln W_{i j t}-X_{i j t} \beta$, it follows that the average wage residual over all workers in establishment $j$ will be given by

$$
\bar{w}_{j t}=\varepsilon_{j}+\bar{\alpha}_{j}+\bar{\varsigma}_{j t} .
$$


In turn, the difference between the $90^{\text {th }}$ and $10^{\text {th }}$ percentiles, in log wage residuals, $\Lambda_{j t}^{90-10}$, is given by (similarly for the $50^{\text {th }}-10^{\text {th }}$ gap, $\Lambda_{j t}^{50-10}$ )

$$
\Lambda_{j t}^{90-10}=w_{j t}^{90}-w_{j t}^{10}=\left(\alpha_{j t}^{90}-\alpha_{j t}^{10}\right)+\left(\varsigma_{j t}^{90}-\varsigma_{j t}^{10}\right) .
$$

Having computed the log wage residuals for year $t$ and $t+1$, for example, one might be interested in testing whether the change $\Delta \Lambda_{j t}^{90-10}$ is a function of the shift in collective bargaining status, controlling for a set of relevant establishment-level characteristics, $X_{j t}^{\prime}$. In this case, the relevant empirical model will be given by

$$
\Delta \Lambda_{j t}^{90-10}=\delta \Delta U_{j t}+X_{j t}^{\prime} \beta+\Delta\left(\varsigma_{j t}^{90}-\varsigma_{j t}^{10}\right),
$$

or

$$
\Delta \Lambda_{j t}^{90-10}=\delta \Delta U_{j t}+X_{j t}^{\prime} \beta^{\prime}+\xi_{j t},
$$

where $U_{j t}$ denotes the dummy for collective bargaining presence and $\xi_{j t}$ is netted out of any establishment or worker unobserved effect.

Our difference-in differences estimate, $\delta$, can only be identified if there are collective bargaining switchers in the sample. Moreover, given that in year $t$ establishment $j$ is either covered or not covered, we observe in principle two types of switchers (i.e. joiners and leavers) along with two types of stayers (i.e. collective bargaining never members and always members). Accordingly, for the subset of joiners (never members) we have $\Delta U_{j t}=1\left(\Delta U_{j t}=0\right)$ and, for the subset of leavers (always members) we have $\Delta U_{j t}=-1\left(\Delta U_{j t}=0\right)$. By construction, we assume that the causal effects of leaving and joining a collective bargaining are not necessarily symmetric.

The entire identification strategy hinges therefore on the assumption that the set of establishments at risk of switching collective bargaining status allow for the estimation of the parameter of interest: the effect of collective bargaining on wage dispersion. Presumably, the obtained estimate will not be valid for any establishment for which the joining/leaving event is very unlikely, which observations are dropped in our matching exercise.

Finally, we seek to estimate both immediate and medium- to long-run effects. To this end, we present results for 1 and 4-year difference-in-differences. In practice, this exercise is carried out by pooling all establishments that are observed in $t$ and $t+1, t$ and $t+2, t$ and $t+3$, and $t$ and $t+4$, and then running, in separate regressions, the changes in residual inequality on the corresponding indicator of collective bargaining transition. ${ }^{6}$ 


\section{Data}

Our analysis is based on the LIAB, a unique linked employer-employee data set for Germany (see Joacobebbinghaus and Seth, 2010) provided by the IAB (Institute for Employment Research/Institut für Arbeitsmarkt- und Berufsforschung of the Federal Employment Agency/Bundesagentur für Arbeit).The LIAB combines official social security insurance data on individuals with establishment data from the IAB Establishment Panel/Betriebspanel. Data access was provided remotely via the Research Data Centre/FDZ of the German Federal Employment Agency at the IAB.

The individual data are taken from the Integrated Employment Biographies/IEB database. The IEB merges official information on employment subject to social security (since 1975), marginal employment (since 1999), unemployment (since 1975), social benefits (since 1975), registered jobseekers (since 2000), and participants in employment or training programs (since 2000). All employees and trainees subject to social security are covered by the data, other than certain types of civil servants (Beamte), the self-employed, and family workers. In total, more than 80 percent of all employed persons in Germany are included in the IEB (Dorner et al., 2010).

The IAB Establishment Panel is a large-scale annual establishment survey that covers up to 16,000 establishments every year, beginning in 1993 in West Germany and extended in 1996 to the former East Germany. The participating establishments are surveyed on a large number of employment policy-related subjects. These include employment development, business policy and performance, investment, collective bargaining, personnel structure and recruitment, remuneration, and working time. This survey is unique in Germany, since it is representative of all industries and establishment sizes nationwide and was conceived as a longitudinal survey from the outset. (For further information on the IAB Establishment Panel, see Fischer et al., 2009).

The LIAB connects the IEB and the Establishment Panel through an establishment identifier available in both datasets. We note parenthetically that the establishment identifier does not distinguish between a 'birth' - that is, a newly-founded establishment - and what might be termed a 're-birth' - that is, a pure change in ownership. However, for present purposes, any misclassification of an establishment as a birth is unlikely to introduce bias because the wage policy is likely to change in either event. 
In the estimation sample, we treat multiple changes in sectoral agreements as response errors. Valid sectoral agreements are treated as a 1/0 dummy, taking the value of 1 if the establishment is covered by a sectoral agreement, 0 if it is not covered by a sectoral collective agreement. (In the interests of simplification we ignore those establishments covered by firm-level agreements.) Furthermore, given the heterogeneity in wage trends between western and eastern Germany, we focus on the former region alone. Consonant with the literature (e.g. Card, Heining, and Kline, 2013; Dustmann et al., 2014; Antonczyk, Fitzenberger, and Sommerfeld, 2010), given that our dataset does not contain precise information on the number of hours worked, we restrict our analysis to those individuals who are full-time workers.

Our raw data covers the period 1996-2008. They contain some 17 million worker-level observations and approximately 49,000 establishment-level observations in respect of establishments with at least 20 full-time employees, the latter restriction being imposed by the need to construct a meaningful measure of intraestablishment wage dispersion. Establishments lacking (financial) turnover information are also excluded from the sample (chiefly from banking, financial services, and public administration). Annually, we observe between 2 and 5 thousand establishments and 1 to 1.5 million workers

The key variable is the average daily gross wage. ${ }^{7}$ As noted earlier, the raw wage variable is top-censored at the contribution limit set by the German social security system. Since we want to compare our summary statistics at worker level with those provided by the literature, wages above the contribution limit will be imputed using separate censored estimations at worker level and for each year. Following Gartner (2005), we then constructed a truncated normal distribution by using the predicted values from the censored regressions as moments and by setting the lower truncation point equal to the contribution limit. As a last step, we replaced censored wage observations by values randomly drawn from this truncated normal distribution. (We deflated wages using the Producer Price Index published by the German Federal Statistical Office; specifically, all wages are expressed in year 2005 values.)

\section{Preliminary Evidence}

Table 1 illustrates some basic characteristics of the wage data: first, at worker level for benchmarking purposes as regards overall wage inequality (columns (1) through 
(4)); and, second at establishment level to provide some initial evidence on intraestablishment wage inequality (columns (5) through (9)).

[Table 1 near here]

As can be seen in column (1), there has been an increase in wages of about $25 \log$ points over the 1996-2008 interval. This sizeable figure cannot, however, be generalized to the entire population. As documented by Card, Heining, and Kline (2013, Table I), using information from the IEB datafile for 1995-2009, there has been a decrease of about $5 \log$ points in the daily wage of the whole population/sample of fulltime workers aged 20-60 in western Germany. Wages are therefore demonstrably higher in $L I A B$ database, a result that is mainly due to the overrepresentation of large establishments in the IAB establishment survey. Trends in wage inequality are nevertheless similar in the two datasets as will be shown below.

Column (2) of the table indicates that there has been a pronounced increase in wage inequality; specifically, a rise of 15 log points in the standard deviation. By German standards, characterized by a high compact wage structure, this increase is quite remarkable. (The coefficient of variation in German of about 0.1 is between one-third and one-quarter of that of Anglo-Saxon countries. ${ }^{8}$ ) Again, for purposes of comparison we note that Card, Heining, and Kline (2013, Table I) report an increase of $13 \log$ points in the standard deviation, while the corresponding coefficient of variation falls in the 0.1-0.15 interval, with a slight upward trend over time.

The same pattern is reflected in other indicators of wage inequality. Thus, columns (3) and (4) of the table show that the gap between the $50^{\text {th }}$ and $10^{\text {th }}$ percentiles and between the $90^{\text {th }}$ and $10^{\text {th }}$ percentiles increased over the period by 15 and $17 \log$ points, respectively. Another useful benchmark here is provided by Antonczyk, Fitzenberger and Sommerfeld's (2010, Table 1) finding of an increase of 10 and 13 log points in the $50^{\text {th }}-10^{\text {th }}$ and $90^{\text {th }}-10^{\text {th }}$ wage gaps, respectively, for males. The corresponding figures for females are 6 and 11 log points. These latter results are obtained using GSES data and pertain to full-time workers aged 25-55 in establishments with 10 or more employees

Intra-establishment wage inequality is next examined using two types of evidence. The first is an unadjusted indicator, based on observed (and imputed) daily wages (columns (6) through (8)); the second is the residual inequality (column (9)), a refined indicator that controls for (observed) human capital variables as was explained in section III. For completeness, column (5) reports the mean establishment 
wage, which unsurprisingly is smaller than the worker-level mean shown in column (1), and is indicative of the higher wages in larger establishments. In turn, the overall (i.e. worker) wage inequality in column (2) is higher by a margin of 8 to $16 \log$ points than the (mean) within-establishment wage inequality measure in column (6). Vulgo: workers are more heterogeneous than establishments.

Columns (7) and (8) show the (mean) unadjusted $50^{\text {th }}-10^{\text {th }}$ and $90^{\text {th }}-10^{\text {th }}$ wage gaps within establishments. The evidence is that the wage inequality within establishments, over the 12-year interval is in the 25-33 log point range in respect of the former gap and between 57 and 72 log points for the latter. In both cases, we observe a steady upward trend of 8 and 15 log points in dispersion over the sample period.

The last column of the table presents the residual inequality or intraestablishment adjusted wage inequality. The results are striking. First, most of the observed inequality within establishments can be explained by observed human capital variables as the mean residual inequality is approximately two-thirds of the intraestablishment wage inequality reported in column (6); that is to say, were all observed (and unadjusted) inequality due to observables, there would be no remaining residual inequality. Second, and more important, the trend in residual inequality replicates those observed for the $90^{\text {th }}-10^{\text {th }}$ and $50^{\text {th }}-10^{\text {th }}$ unadjusted wage gaps. These trends are graphed in panel (a) of Figure 1. The trends in residual inequality and overall worker wage inequality are also similar, as can be seen from panel (b) of the figure.

\section{[Figure 1 near here]}

The next issue of course is the extent to which the changes in wage inequality can be allocated to shifts in collective bargaining. Since coverage by collective agreements in our data pertains to the establishment, we will focus exclusively on establishment-level information.

\section{Regression Results}

The sample size of the selected comparison groups in our raw longitudinal dataset is given in Table 2. The groups are defined using observed establishment collective bargaining status. They comprise collective agreement leavers and collective agreement always members (in panel (a)) and collective agreement joiners and collective agreement never members (in panel (b)). In each panel, establishments are ob- 
served in $t$ and $t+\tau, \tau=1,2,3,4$, yielding the four columns shown in the table. (Note that an establishment observed in $t$ and $t+4$ is not necessarily observed in $t$ and $t+2$, for example.) Accordingly, over the entire 1996-2008 interval, we have a total of 21,354 cases in which is possible to observe an establishment in two consecutive years, with $20,081 / 21,354$ or 94 percent recording no change in sectoral agreement status and 1,273/21,354 or 6 percent switching from sectoral bargaining into no collective bargaining at all. Similarly, we have 8,980 establishments that are either not covered by any sectoral agreement over two consecutive years (a total of 1,083 cases) or not covered in $t$ but covered in $t+1$ (7,897 cases).

[Table 2 near here]

The decreasing number of cases observed as we move from left to right shows that the longer is the length of the time window, the lower is the number of establishments in the treated and comparison groups, as the likelihood of an establishment being observed in $t$ and $t+\tau$ is decreasing in $\tau$. In any event, there is a reasonably large number of cases in which establishments are observed in $t$ and $t+4$, even if the percentage of those 'treated' relative to the 'untreated' is reduced in this scenario.

[Table 3 near here]

The raw evidence on changes in intra-establishment residual inequality is given in Table 3. The first column of the table, for example, suggests that leaving a collective agreement implies increased wage inequality within establishments one year after the regime shift vis-à-vis always members. As far as joiners are concerned, the evidence in panel (b) suggests that joiners, too, tend to have a higher residual inequality than the comparison group of never members. But the magnitude of the standard deviations reported in the table strongly suggests that the comparator groups need to be further refined. As a first step, we tackle this issue by presenting the matching procedures and the corresponding diagnostic tests. We then estimate the causal effect in a conditional difference-in-differences framework.

Our matching procedure is based on a probit estimation of the probability of leaving/joining a collective agreement, controlling for a wide set of covariates. These include the per capita log wage, the ratio of labor costs to sales, log sales, the share of female/part-time/temporary/and low-skilled employees, the proportion of employees subject to the German social insurance scheme, and a set of dummy variables 
denoting the legal form of the establishment, firm profitability, foreign ownership, firm size, industry, and location.

[Tables 4 and 5 near here]

Probit estimates of the probability of a change in bargaining status for our respective groups of leavers (vs. always members) and joiners (vs. always members) are provided in Tables 4 and 5. They display symmetric coefficients for the most part. Higher average wages seem to increase the probability of leaving a sectoral agreement, while lower wages are likely to increase the probability of joining one. Also, a low (high) share of labor costs, indicating the capital intensity of production, increases the probability of leaving (joining) collective agreement. A similar effect obtains in the case of establishment sales. It would appear therefore that larger firms tend to join collective agreements, whereas smaller establishments are more likely to leave, all else constant. Leavers (joiners) are also more likely to have a lower (higher) share of part-timers and employees subject to the social insurance scheme. But with respect to the proportion of temporary, low-skilled workers and the presence of foreign ownership, the evidence fails to reveal any obvious symmetry. ${ }^{9}$

The corresponding propensity scores obtained from these probits were next used to conduct a radius matching exercise with a caliper of 0.001 around the estimated values. (The diagnostics are provided in Appendix Tables 1 and 2; and with one exception - joiners in the fourth column, last two row entries, of Appendix Table 2 - the matching quality is very high.) After applying the matching procedures, the number of observations for estimation purposes (in Table 6 below) falls to one-third to one-half of those given in Table 2. For example, while the total number of cases in the first column of panel (a) of Table 2 is 21,354, the actual estimation sample size (given in the first column of Table 6, is 9,008 establishments.

[Table 6 near here]

Turning therefore to the difference-in-differences estimates of the effect of collective bargaining on wage inequality, results for leavers vs. always members are given in Table 6, and for joiners vs. never members in Table 7. The exercise uses two types of outcomes: (observed) establishment wage dispersion, in panel (a), and (unobserved) residual inequality in panel (b), including in the latter panel results for the $50^{\text {th }}-10^{\text {th }}$ and $90^{\text {th }}-10^{\text {th }}$ wage gaps based on log wage residuals as described in section III. 
Beginning with the results for leavers in Table 6, panel (a) fails to indicate any impact of exiting sectoral bargaining on either the standard deviation of intraestablishment earnings or the $50^{\text {th }}-10^{\text {th }}$ and $90^{\text {th }}-10^{\text {th }}$ wage gaps. Surprisingly, then, there is no sign of any obvious role for collective bargaining on (observed) wage dispersion even four years after the selected event/treatment.

In panel (b) of the table, however, we do find a statistically significant effect of collective agreements on wage inequality. That is, once we compare the wages of observationally equal individuals we find that collective agreements do matter: adjusted wage dispersion across co-workers increases after an establishment's exit from a collective agreement. To this extent, our presumption that collective agreement is favorable to wage compression is confirmed. Specifically, $\sigma_{j t}$ in the first row of panel (b) is estimated to increase on average by approximately 2 log points, which is approximately 10 percent of the intra-establishment mean residual inequality obtaining over the sample period (see column (9) of Table 1). The fact that the 4-year effect is statistically insignificant is likely to be explained more by the reduced sample size than anything else. Finally, the results are weaker for the $50^{\text {th }}-10^{\text {th }}$ gap in residual inequality, although the effect of leaving on the $90^{\text {th }}-10^{\text {th }}$ gap is both larger and better determined.

\section{[Table 7 near here]}

Table 7 presents a similar exercise for collective agreement joiners versus never members. The background here is that the number of observations is roughly one-half that of those in Table 6. There are two main reasons for this: first, given that collective bargaining is in decline, the number of joiners is smaller than the number of leavers; second, given that sectoral bargaining remains the dominant regime, we have necessarily fewer never members than always members in the sample.

For both observed and unobserved inequality, there is just one statistically significant effect of signing on to a collective agreement (and here only at the .10 level). In one sense this is surprising in that the effects on wages should be stronger - at least initially - in the case of joining an agreement than leaving one because of the Nachwirkungsfrist doctrine. ${ }^{10}$ If however sectoral agreements are offering joiners more flexible terms than heretofore, then joining a collective agreement may not generate material changes in dispersion. 


\section{Conclusions}

Despite the growing number of studies pointing to collective bargaining decline as one of the main candidates to explain rising wage inequality, the exact contribution of deunionization is still a matter of debate. This study has approached the question by examining intra-plant wage dispersion in the wake of establishments either exiting from or entering into collective agreements. Our expectation was that for the set of establishments at risk of leaving/joining, we should observe a clear tendency towards reduced/heightened wage compression. In other words, we would not expect to observe decreasing within-establishment wage dispersion among workers in plants exiting collective agreements or the converse among employees in plants joining them, one, two, three, and four years after the change in collective bargaining status.

To address the source of rising wage inequality widely documented in the literature we selected therefore a rather direct approach, focusing on actual collective bargaining transitions observed over a period in which the decline in collective agreement coverage is well documented. Given that coverage is observed at establishment level, our preferred measure of wage dispersion was within-establishment adjusted wage inequality (or residual inequality), a measure that by definition is net of differences in human capital observed at worker (and firm) level.

For leavers we found an increase of approximately 2 log points in the adjusted wage inequality, or a 10 percent increase if one takes as the point of reference the average level of wage inequality observed over the sample period (viz. 0.206). We also found statistically significant effects on the $50^{\text {th }}-10^{\text {th }}$ and $90^{\text {th }}-10^{\text {th }}$ adjusted wage gaps. Perhaps unexpectedly, the impact of leaving a collective agreement did not seem to visibly increase over time, although the 'perverse' result that after 4 years the widening effect disappears/becomes statistically insignificant can most plausibly be attributed to data limitations. In any event, the principal result for leavers is the evidence of non-trivial immediate to medium-term effects - effects that will come as a surprise to those anticipating continuing legal constraints in the wake of opting out.

There is nevertheless scant evidence that joining a collective agreement produces a symmetric effect. Indeed, although in the raw (unadjusted) wage dispersion data there is some indication that joining is associated with lower wage compression, this result is contraindicated using our preferred measures of residual inequality.

Taken in the round, our results cast doubt on the notion that shifts in collective bargaining underpin rising wage inequality, although we can confirm that since the 
mid-1990s there has been an increase in both overall (worker) and withinestablishment (both unadjusted and adjusted) wage dispersion. That is, the magnitude of the effects detected here, underscored by their lack of symmetry, offer insufficient evidence to support the claim that changes in wage inequality are produced by deunionization. That said, other collective bargaining developments in the form of opening clauses and pacts for employment and competitiveness may have played a more important role than coverage in contemporary wage developments and evolving wage dispersion. Since the role of these institutional innovations on collective bargaining structure is rather indirect, their analysis requires a quite different modeling strategy than has been employed here in considering the external erosion of collective bargaining. Issues of internal erosion are now likely to assume center stage in the analysis of the effects of collective bargaining upon wage dispersion. 


\section{ENDNOTES}

1. As described in section IV, the observation window for our linked employeremployee dataset covers the period 1996-2008. Over this interval on only two occasions were plants in the component establishment dataset asked about the presence of opening clauses and company pacts (in 2005/2007 and 2006/2008, respectively). While insufficient for our purposes, these two data have been used to study the impact of opening clauses on wages (see for example, Garloff and Gürtzgen, 2012; Brändle, 2013; Ellguth, Gerner, and Stegmaier, 2014).

2. Their findings again pertain to western Germany, reflecting disparate wage trends in the two halves of Germany (on which, see Kohn and Lembcke, 2007).

3. Specifically, deunionization has stronger effects on rising dispersion at the top of the distribution.

4. Card, Heining, and Kline also provide alternative counterfactual scenarios to further illustrate the relative importance of these three effects.

5. Note, however, that the models emphasizing firm heterogeneity do not control for contract heterogeneity (though for one such attempt using Portuguese data, see Torres, Portugal, Addison, and Guimarães, 2014). In short, any such contract effect will be included within the other two effects assuming these are separately identified.

6. Although this design allow us to look at, say, immediate and medium- to log-run effects of collective bargaining on wage dispersion, note that the estimation results reported below do use a different set of establishments. Thus, the 4-year effect is based on a much smaller sample than the 1-year effect, due simply to the fact that an establishment is much more likely to be observed in $t$ and $t+1$ than in $t$ and $t+4$.

7. According to the FDZ DatenReport 04/2007 (Spengler, 2007, p. 26), "to determine the gross daily wage, the wage for the duration of the given period is divided by the number of calendar days within the period and the value obtained rounded to two decimal points." In practice, given that we are looking only at full-time workers, the denominator is equal to 365 days if the worker has just one full time job in a year. According to Card, Heining and Kline (2013), a full-time worker in Germany holds some 1.1 jobs in a year.

8. On average over the selected period, the median wage earner earns some 50 percent more than an individual in the $10^{\text {th }}$ percentile, while an individual in the $90^{\text {th }}$ percentile is estimated to earn roughly twice as much as his/her counterpart in the $10^{\text {th }}$ percentile.

9. See Addison et al. (2013) for a full discussion of the determinants of collective bargaining 'survivability' in German establishments.

10. Under German law those leaving a collective agreement are supposed to pay wages for incumbent (but not new) employees according to the old collective agreement and to do so until a new agreement has been reached at firm level or as a result of individual bargaining. They are not of course subject to subsequent revisions of the old contract. It is therefore possible that being uncovered still requires payment 
according to an active contract. For our proposes here we simply choose to infer that the longer the respondent claims to be no longer covered by a collective agreement, the longer that establishment has left a collective agreement and the further adrift of current contracts are the wages in that establishment. Note, however, that if there is some slippage in the equation of leaving collective bargaining with not being covered by a collective agreement, no such imprecision applies to 'joiners' who have immediately to meet the terms of the relevant collective agreement. 


\section{References}

Abowd, John M., Francis Kramarz, and David N. Margolis. 1999. "High Wage Workers and High Wage Firms." Econometrica 67(2): 251-334.

Addison, John T., Ralph W. Bailey, and W. Stanley Siebert. 2007. "The Impact of Deunionization on Earnings Determination Revisited." Research in Labor Economics 26(2): 337-363.

Addison, John, T., Paulino Teixeira, Alex Bryson, and André Pahnke. 2013. "Collective Agreement Status and Survivability: Change and Persistence in the German Model." Labour: Review of Labour Economics and Industrial Relations 27(3): 288309.

Addison, John T., Paulino Teixeira, Katalin Evers, and Lutz Bellmann. 2014. "Indicative and Updated Estimates of the Collective Bargaining Premium in Germany." Industrial Relations 53(1): 125-256.

Antonczyk, Dirk. 2010. "Using Social Norms to Estimate the Effect of Collective Bargaining on the Wage Structure." Mimeographed, Albert-Ludwigs-Universität Freiburg, November.

Antonczyk, Dirk, Bernd Fitzenberger, and Katrin Sommerfeld. 2010. "Rising Wage Inequality, the Decline of Collective Bargaining, and the Gender Wage Gap." Labour Economics 17(5): 835-847.

Bechtel, Stephan, Patrizia Mödinger, and Harald Strotmann. 2004. "Tarif- und Lohnstrukturen in Baden-Württemberg: Entwicklung und Einfluss der Tarifbindung auf Verdiensthöhe und -streuung." Statistische Analysen 7: 1-44.

Brändle, Tobias. 2013. "Flexible Collective Bargaining Agreements: Still a Moderating Impact on Works Council Behavior?" Mimeographed, Institute for Applied Economic Research Tübingen, October.

Card, David. 1996. "The Effect of Unions on the Structure of Wages: A Longitudinal Analysis." Econometrica 64(4): 957-979.

Card, David, Jörg Heining, and Patrick Kline. 2013. "Workplace Heterogeneity and the Rise of West German Wage Inequality." Quarterly Journal of Economics 128(3): 967-1015.

Dinardo, John E., Nicole Fortin, and Thomas Lemieux. 1996. "Labor Market Institutions and the Distribution of Wages, 1973-1992: A Semiparametric Approach." Econometrica 64(5): 1001-1044.

Dorner, Matthias, Jörg Heining, Peter Jacobebbinghaus, and Stephan Seth. 2010. "Sample of Integrated Labour Market Biographies (SIAB) 1975-2008." FDZDatenreport 01/2010.

Dustmann, Christian, Johannes Ludsteck, and Uta Schönberg. 2009. "Revisiting the German Wage Structure." Quarterly Journal of Economics 124(2): 843-881. 
Dustmann, Christian, Bernd Fitzenberger Uta Schönberg, and Alexandra SpitzOener. 2014. "From Sick Man of Europe to Economic Superstar: Germany's Resurgent Economy." Journal of Economic Pespectives 28(1): 167-188.

Ellguth, Peter, Hans-Dieter Gerner, and Jens Stegmaier. 2014. "Wage Effects of Works Councils and Opening Clauses: The German Case." Economic and Industrial Democracy 35(1): 95-113.

Fischer, Gabriele, Florian Janik, Dana Müller, and Alexandra Schmucker. 2009. "The IAB Establishment Panel: Things Users Should Know." Schmollers Jahrbuch 129(1): 133-148.

Fitzenberger, Bernd, Karsten Kohn, and Alexander C. Lembcke. 2013. "Union Density and Varieties of Coverage: The Anatomy of Union Wage Effects in Germany." Industrial and Labor Relations Review 66(1): 169-197.

Freeman, Richard B. 1982. "Unionism and the Dispersion of Wages." Industrial and Labor Relations Review 34(1): 3-23.

Garloff, Alfred, and Nicole Gürtzgen. 2012. "Collective Wage Contracts, Opt-Out Clauses and Firm Wage-Differentials: Evidence from Linked Employer Employee Data." Industrial Relations 51(3): 731-748.

Gartner, Hermann. 2005. "The imputation of wages above the contribution limit with the German IAB employment sample." FDZ-Methodenreport, 02/2005.

Gerlach, Knut, and Gesine Stephan. 2002. "Tarifverträge und Lohnstruktur in Niedersachsen." Statistische Monatshefte Niedersachen 56(10): 543-552.

Gerlach, Knut, and Gesine Stephan. 2006a. "Bargaining Regimes and Wage Dispersion." Jahrbücher für Nationalökonomie und Statistik 126(6): 629-649.

Gerlach, Knut, and Gesine Stephan. 2006b." Pay Policies of Firms and Collective Wage Contracts - An Uneasy Partnership." Industrial Relations 45(1): 47-67.

Guertzgen, Nicole. 2014. "Estimating the Wage Premium of Collective Wage Contracts - Evidence from Longitudinal Linked Employer-Employee Data." Industrial Relations (forthcoming).

Hirsch, Barry T. 2004. "Reconsidering Union Wage Effects: Surveying New Evidence on an Old Topic." Journal of Labor Research 25(2); 233-266.

Jacobebbinghaus, Peter, and Stephan Seth. 2010. "Linked Employer-Employee Data from the IAB: LIAB Cross-sectional (Model 2, 1993-2008)." FDZ-Datenreport 05/2010.

Kohn, Karsten, and Alexander C. Lembcke. 2007. "Wage Distributions by Bargaining Regime - Linked Employer-Employee Data Evidence from Germany." AstA Wirtschafts- und Sozialstatistisches Archiv (3-4): 247-261. 
Lewis, H. Gregg. 1996. Union Relative Wage Effects: A Survey. Chicago, IL: University of Chicago Press.

Pontusson, Jonas. 2013. "Unionization, Inequality, and Redistribution." British Journal of Industrial Relations 51(4): 787-825.

Riso-Avila, Fernando, and Barry T. Hirsch. "Unions, Wage Gaps, and Wage Dispersion: New Evidence from the Americas." Industrial Relations 53(1): 1-27.

Roy, Andrew. 1951. "Some thoughts on the distribution of earnings. Oxford Economic Papers 3: 135-146

Rubin, Donald. 1974. Estimating causal effects of treatments in randomized and nonrandomized studies. Journal of Educational Psychology 66: 688-701.

Spengler, Anja. 2007. "The Establishment History Panel 1975-2005: Handbook Version 2.0.0." FDZ DatenReport 04/2007.

Torres, Sonia, Pedro Portugal, John T. Addison, and Paulo Guimarães. 2014. "The Sources of Wage Variation: A Three-Way High-Dimensional Fixed Effects Regression Model." Mimeographed, University of South Carolina, July.

Winter-Ebmer, Rudolf, and Josef Zweimüller. 1999. "Intra-firm Wage Dispersion and Firm Performance." Kyklos 52(4): 555-572. 
Table 1: Summary statistics and residual inequality for the LIAB sample of full-time workers in establishments with at least 20 employees, western Germany, 1996-2008

\begin{tabular}{|c|c|c|c|c|c|c|c|c|c|}
\hline \multirow[b]{2}{*}{ Year } & \multicolumn{4}{|c|}{ Worker daily wage } & \multirow{2}{*}{$\begin{array}{l}\text { Mean establish- } \\
\text { ment daily wage } \\
\text { [number of firms] } \\
\text { (5) }\end{array}$} & \multicolumn{3}{|c|}{ Intra-establishment wage inequality } & \multirow{2}{*}{$\begin{array}{l}\text { Intra-establishment } \\
\text { residual inequality } \\
\text { Mean (s.d.) } \\
\text { (9) }\end{array}$} \\
\hline & $\begin{array}{l}\text { Mean [number of } \\
\text { workers] } \\
\text { (1) }\end{array}$ & $\begin{array}{l}\text { s.d. } \\
\text { (2) }\end{array}$ & $\begin{array}{c}50^{\text {th }}-10^{\text {th }} \\
\text { gap } \\
(3)\end{array}$ & $\begin{array}{c}90^{\text {th }}-10^{\text {th }} \\
\text { gap } \\
(4)\end{array}$ & & $\begin{array}{c}\text { Mean (s.d.) } \\
\text { (6) }\end{array}$ & $\begin{array}{c}50^{\text {th }}-10^{\text {th }} \\
\text { gap } \\
\text { (7) }\end{array}$ & $\begin{array}{c}90^{\text {th }}-10^{\text {th }} \\
\text { gap } \\
\text { (8) }\end{array}$ & \\
\hline 1996 & $4.395[2,075,126]$ & 0.346 & 0.424 & 0.906 & $4.203[5,835]$ & $0.247(0.087)$ & 0.253 & 0.572 & $0.170(0.068)$ \\
\hline 1997 & $4.417[1,764,141]$ & 0.348 & 0.426 & 0.904 & $4.210[5,185]$ & $0.250(0.093)$ & 0.251 & 0.572 & $0.172(0.069)$ \\
\hline 2000 & $4.495[1,786,932]$ & 0.423 & 0.449 & 0.913 & $4.291[8,170]$ & $0.325(0.213)$ & 0.312 & 0.686 & $0.217(0.123)$ \\
\hline 2001 & $4.497[1,918,039]$ & 0.392 & 0.457 & 0.914 & $4.301[9,046]$ & $0.310(0.168)$ & 0.325 & 0.666 & $0.212(0.125)$ \\
\hline 2002 & $4.528[1,788,076]$ & 0.386 & 0.444 & 0.885 & $4.320[8,523]$ & $0.306(0.164)$ & 0.322 & 0.659 & $0.205(0.121)$ \\
\hline 2003 & $4.559[1,608,658]$ & 0.407 & 0.461 & 0.986 & $4.335[8,134]$ & $0.310(0.160)$ & 0.326 & 0.684 & $0.202(0.109)$ \\
\hline 2007 & $4,639[1,439,236]$ & 0,482 & 0,550 & 1.049 & $4.373 ; 7,508]$ & $0.338(0.209)$ & 0.334 & 0.720 & $0.224(0.119)$ \\
\hline 2008 & $4,653[1,392,886]$ & 0,496 & 0,577 & 1.074 & $4.377[7,367]$ & $0.337(0.186)$ & 0.337 & 0.721 & $0.228(0.128)$ \\
\hline
\end{tabular}

Notes: Gross daily wages are deflated using the producer price index and are expressed in year 2005 values. Wages above the contribution limit to the social security system were imputed using the procedure suggested by Gartner (2005). Both observed and imputed wages are used to compute the values reported in columns (1) through (8). Column (5) gives the mean establishment daily wage across all establishments in the sample. The value reported in column (6) is obtained by taking the average over all intra-establishment standard deviations in a given year, and the corresponding standard deviation over all establishments is provided in parentheses in the same column. Column (9) gives the intra-establishment residual inequality, or $\sigma_{j t}$ (see section III). 
Table 2: Sample size of selected groups, establishments with at least 20 employees, LIAB data, 1996-2008

\begin{tabular}{|c|c|c|c|c|}
\hline & \multicolumn{4}{|c|}{ Sample size } \\
\hline & $t+1$ & $t+2$ & $t+3$ & $t+4$ \\
\hline \multicolumn{5}{|l|}{ (a) Leavers and always members } \\
\hline $\begin{array}{l}\text { Number of leavers (i.e. establishments leaving a collec- } \\
\text { tive agreement between } t \text { and } t+\tau, \tau=1,2,3,4 \text { ) }\end{array}$ & 1,273 & 532 & 309 & 201 \\
\hline $\begin{array}{l}\text { Number of always members (i.e. establishments that } \\
\text { are always covered by a collective agreement between } t \\
\text { and } t+\tau, \tau=1,2,3,4 \text { ) }\end{array}$ & 20,081 & 13,919 & 9,828 & 7,029 \\
\hline Total & 21,354 & 14,451 & 10,137 & 7,230 \\
\hline \multicolumn{5}{|l|}{ (b) Joiners and never members } \\
\hline $\begin{array}{l}\text { Number of joiners (i.e. establishments joining a collec- } \\
\text { tive agreement between } t \text { and } t+\tau, \tau=1,2,3,4 \text { ) }\end{array}$ & 1,083 & 444 & 238 & 150 \\
\hline $\begin{array}{l}\text { Number of never members (i.e. establishments that are } \\
\text { never covered by a collective agreement between } t \text { and } \\
t+\tau, \tau=1,2,3,4)\end{array}$ & 7,897 & 4,912 & 3,197 & 2,086 \\
\hline Total & 8,980 & 5,356 & 3,435 & 2,236 \\
\hline
\end{tabular}

Note: The total of 21,354 in the third cell of the first column of the table, for example, gives the number of annual transitions from the initial state in which an establishment is covered by a sectoral agreement (or the sum of 1,273 leavers and 20,081 stayers). 
Table 3: Changes in residual intra-establishment wage dispersion for selected groups between $t$ and $t+\tau(\tau=1,2,3,4)$, establishments with at least 20 employees, LIAB data, 1996-2008, before matching

\begin{tabular}{|c|c|c|c|c|}
\hline & $\mathrm{t}+1$ & $t+2$ & $\mathrm{t}+3$ & $t+4$ \\
\hline & $\begin{array}{l}\text { Mean } \\
\text { (s.d.) }\end{array}$ & $\begin{array}{l}\text { Mean } \\
\text { (s.d.) }\end{array}$ & $\begin{array}{c}\text { Mean } \\
\text { (s.d.) }\end{array}$ & $\begin{array}{l}\text { Mean } \\
\text { (s.d.) }\end{array}$ \\
\hline \multicolumn{5}{|l|}{ (a) Leavers and always members } \\
\hline $\begin{array}{l}\text { Leavers (i.e. establishments leaving a collective } \\
\text { agreement between } t \text { and } t+1 \text { and did not join } \\
\text { collective agreement in } t+\tau, \tau=1,2,3,4 \text { ) }\end{array}$ & $\begin{array}{c}0.006 \\
(0.110)\end{array}$ & $\begin{array}{c}0.001 \\
(0.131)\end{array}$ & $\begin{array}{l}-0.001 \\
(0.145)\end{array}$ & $\begin{array}{l}-0.006 \\
(0.161)\end{array}$ \\
\hline $\begin{array}{l}\text { Always members (i.e. establishments that are al- } \\
\text { ways covered by a collective agreement between } t \\
\text { and } t+\tau, \tau=1,2,3,4 \text { ) }\end{array}$ & $\begin{array}{c}0.004 \\
(0.099)\end{array}$ & $\begin{array}{c}0.006 \\
(0.105)\end{array}$ & $\begin{array}{c}0.008 \\
(0.111)\end{array}$ & $\begin{array}{c}0.009 \\
(0.114)\end{array}$ \\
\hline \multicolumn{5}{|l|}{ (b) Joiners and never members } \\
\hline $\begin{array}{l}\text { Joiners (i.e. establishments joining a collective } \\
\text { agreement between } t \text { and } t+1 \text { and did not leave } \\
\text { collective agreement in } t+\tau \text {, and } t+\tau, \tau= \\
1,2,3,4 \text { ) }\end{array}$ & $\begin{array}{c}0.007 \\
(0.134)\end{array}$ & $\begin{array}{c}0.003 \\
(0.117)\end{array}$ & $\begin{array}{c}0.009 \\
(0.188)\end{array}$ & $\begin{array}{c}0.011 \\
(0.221)\end{array}$ \\
\hline $\begin{array}{l}\text { Never members (i.e. establishments that are never } \\
\text { covered by a collective agreement between } t \text { and } \\
t+\tau, \tau=1,2,3,4)\end{array}$ & $\begin{array}{c}0.003 \\
(0.106)\end{array}$ & $\begin{array}{c}0.008 \\
(0.155)\end{array}$ & $\begin{array}{c}0.014 \\
(0.122)\end{array}$ & $\begin{array}{c}0.014 \\
(0.123)\end{array}$ \\
\hline
\end{tabular}

Notes: The value reported in the first cell, for example, is the mean 1-year difference in $\Delta \sigma_{j t}$ for leavers; the corresponding standard deviation is in parenthesis. $\sigma_{j t}$ gives the degree of (residual) intra-establishment wage inequality (see section III). 
Table 4: Probit estimates of the probability of an establishment leaving a collective agreement in $t+\tau$, given that it is covered by a collective agreement in $t$.

\begin{tabular}{|c|c|c|c|c|}
\hline & $t+1$ & $t+2$ & $t+3$ & $t+4$ \\
\hline Log wage per capita & $\begin{array}{c}0.319 * * \\
(0.103)\end{array}$ & $\begin{array}{c}0.406^{*} \\
(0.161)\end{array}$ & $\begin{array}{c}0.633^{* *} \\
(0.211)\end{array}$ & $\begin{array}{c}0.361 \\
(0.296)\end{array}$ \\
\hline Share of labour costs & $\begin{array}{l}-0.841^{* *} \\
(0.296)\end{array}$ & $\begin{array}{l}-0.847 \\
(0.457) \\
\end{array}$ & $\begin{array}{l}-1.531^{*} \\
(0.608) \\
\end{array}$ & $\begin{array}{l}-0.904 \\
(0.835) \\
\end{array}$ \\
\hline (Lagged) log sales & $\begin{array}{l}-0.243^{* *} \\
(0.063)\end{array}$ & $\begin{array}{l}-0.262^{* *} \\
(0.099) \\
\end{array}$ & $\begin{array}{l}-0.506^{* *} \\
(0.137) \\
\end{array}$ & $\begin{array}{l}-0.270 \\
(0.179)\end{array}$ \\
\hline Share of part-time workers & $\begin{array}{c}-0.512 * \\
(0.215) \\
\end{array}$ & $\begin{array}{l}-0.927^{* *} \\
(0.327) \\
\end{array}$ & $\begin{array}{l}-1.154^{* *} \\
(0.411) \\
\end{array}$ & $\begin{array}{l}-1.789 * * \\
(0.623) \\
\end{array}$ \\
\hline Share of temporary employment & $\begin{array}{c}1.085^{* *} \\
(0.247) \\
\end{array}$ & $\begin{array}{c}1.220^{* *} \\
(0.360) \\
\end{array}$ & $\begin{array}{c}1.295^{* *} \\
(0.448) \\
\end{array}$ & $\begin{array}{c}2.081^{* *} \\
(0.575) \\
\end{array}$ \\
\hline Share of employment subject to social security & $\begin{array}{l}-1.009^{* *} \\
(0.274)\end{array}$ & $\begin{array}{l}-1.735^{* *} \\
(0.419)\end{array}$ & $\begin{array}{l}-1.133^{*} \\
(0.557)\end{array}$ & $\begin{array}{l}-1.222 \\
(0.820) \\
\end{array}$ \\
\hline Share of female workers & $\begin{array}{c}0.505^{* *} \\
(0.139)\end{array}$ & $\begin{array}{c}0.549 * * \\
(0.211)\end{array}$ & $\begin{array}{c}0.732 * * \\
(0.260)\end{array}$ & $\begin{array}{c}1.031^{* *} \\
(0.349)\end{array}$ \\
\hline Share of low-skilled workers & $\begin{array}{l}-0.279 * * \\
(0.104) \\
\end{array}$ & $\begin{array}{l}-0.200 \\
(0.159) \\
\end{array}$ & $\begin{array}{l}-0.240 \\
(0.199) \\
\end{array}$ & $\begin{array}{l}-0.106 \\
(0.259) \\
\end{array}$ \\
\hline Foreign ownership & $\begin{array}{l}-0.102 \\
(0.100) \\
\end{array}$ & $\begin{array}{l}-0.326 \\
(0.172) \\
\end{array}$ & $\begin{array}{l}-0.280 \\
(0.208) \\
\end{array}$ & $\begin{array}{l}-0.777 \\
(0.400) \\
\end{array}$ \\
\hline Constant & $\begin{array}{c}1.040 \\
(0.787) \\
\end{array}$ & $\begin{array}{c}1.033 \\
(1.220) \\
\end{array}$ & $\begin{array}{c}2.323 \\
(1.641) \\
\end{array}$ & $\begin{array}{c}0.247 \\
(2.106) \\
\end{array}$ \\
\hline Likelihood ratio & $455.14 * *$ & $284.94 * *$ & $163.83 * *$ & $115.70 * *$ \\
\hline Log likelihood & -1785.23 & -782.16 & -490.98 & -277.22 \\
\hline Pseudo $\mathrm{R}^{2}$ & 0.1131 & 0.1541 & 0.1430 & 0.1727 \\
\hline Observations & 9,008 & 5,155 & 3,369 & 2,237 \\
\hline
\end{tabular}

Notes: The model also includes the following dichotomous variables: establishment size (seven dummies), legal form (five), firm profitability (five), industry (fourteen), year (twelve) and region (eight). ${ }^{* *}, * *$, and ${ }^{*}$ denote significance at the $.01, .05$, and .10 levels, respectively. 
Table 5: Probit estimates of the probability of an establishment joining a collective agreement in $t+\tau$, given that it is not covered by a collective agreement in $t$.

\begin{tabular}{|c|c|c|c|c|}
\hline & $t+1$ & $t+2$ & $t+3$ & $t+4$ \\
\hline Log wage per capita & $\begin{array}{l}-0.395^{* *} \\
(0.114)\end{array}$ & $\begin{array}{l}-0.565^{* *} \\
(0.180)\end{array}$ & $\begin{array}{l}-1.296 * * \\
(0.288)\end{array}$ & $\begin{array}{l}-2.096^{* *} \\
(0.473)\end{array}$ \\
\hline Share of labour costs & $\begin{array}{c}0.654^{*} \\
(0.318)\end{array}$ & $\begin{array}{c}1.348^{* *} \\
(0.497)\end{array}$ & $\begin{array}{c}3.311^{* *} \\
(0.757)\end{array}$ & $\begin{array}{c}5.095^{* *} \\
(1.170)\end{array}$ \\
\hline (Lagged) log sales & $\begin{array}{c}0.064 \\
(0.073)\end{array}$ & $\begin{array}{c}0.147 \\
(0.112) \\
\end{array}$ & $\begin{array}{c}0.321 \\
(0.170)\end{array}$ & $\begin{array}{c}0.708^{* *} \\
(0.262)\end{array}$ \\
\hline Share of part-time workers & $\begin{array}{c}0.612^{* *} \\
(0.236)\end{array}$ & $\begin{array}{c}0.890^{*} \\
(0.404)\end{array}$ & $\begin{array}{c}1.436 * \\
(0.596)\end{array}$ & $\begin{array}{c}2.816^{* *} \\
(0.896)\end{array}$ \\
\hline Share of temporary employment & $\begin{array}{c}0.495 \\
(0.257)\end{array}$ & $\begin{array}{c}0.554 \\
(0.465)\end{array}$ & $\begin{array}{l}-0.100 \\
(0.744)\end{array}$ & $\begin{array}{c}1.428 \\
(1.079)\end{array}$ \\
\hline Share of employment subject to social security & $\begin{array}{c}0.538 \\
(0.304)\end{array}$ & $\begin{array}{c}1.414^{* *} \\
(0.533)\end{array}$ & $\begin{array}{c}3.047^{* *} \\
(0.897)\end{array}$ & $\begin{array}{c}3.476^{* *} \\
(1.310)\end{array}$ \\
\hline Share of female workers & $\begin{array}{l}-0.575^{* *} \\
(0.154)\end{array}$ & $\begin{array}{l}-0.809 * * \\
(0.259)\end{array}$ & $\begin{array}{l}-1.143^{* *} \\
(0.368) \\
\end{array}$ & $\begin{array}{l}-2.080^{* *} \\
(0.611)\end{array}$ \\
\hline Share of low-skilled workers & $\begin{array}{l}-0.369 * * \\
(0.122)\end{array}$ & $\begin{array}{l}-0.354 \\
(0.193) \\
\end{array}$ & $\begin{array}{l}-0.035 \\
(0.277) \\
\end{array}$ & $\begin{array}{c}0.005 \\
(0.394) \\
\end{array}$ \\
\hline Foreign ownership & $\begin{array}{l}-0.290^{*} \\
(0.130)\end{array}$ & $\begin{array}{l}-0.240 \\
(0.197)\end{array}$ & $\begin{array}{l}-0.631 \\
(0.347)\end{array}$ & $\begin{array}{l}-0.429 \\
(0.394) \\
\end{array}$ \\
\hline Constant & $\begin{array}{c}0.224 \\
(0.962) \\
\end{array}$ & $\begin{array}{l}-0.409 \\
(1.523) \\
\end{array}$ & $\begin{array}{c}0.412 \\
(2.361) \\
\end{array}$ & $\begin{array}{l}-0.503 \\
(3.224) \\
\end{array}$ \\
\hline Likelihood ratio & $209.95 * *$ & $135.79 * *$ & $135.62 * *$ & $117.09 * *$ \\
\hline Log likelihood & -1215.91 & -456.40 & -205.77 & -112.79 \\
\hline Pseudo $\mathrm{R}^{2}$ & 0.0795 & 0.1295 & 0.2479 & 0.3417 \\
\hline Observations & 4,269 & 2,337 & 1,373 & 817 \\
\hline
\end{tabular}

Note: See notes to Table 4. 
Table 6: Conditional difference-in-difference estimates of the effect of collective bargaining using collective agreement leavers vs. always members

\begin{tabular}{|c|c|c|c|c|}
\hline Parameter of interest & 1-year effect & 2-year effect & 3-year effect & 4-year effect \\
\hline \multicolumn{5}{|l|}{$\begin{array}{l}\text { (a) Intra-establishment (log) } \\
\text { wage dispersion: }\end{array}$} \\
\hline Standard deviation & $\begin{array}{c}0.004 \\
(0.009)\end{array}$ & $\begin{array}{l}-0.008 \\
(0.016)\end{array}$ & $\begin{array}{c}0.002 \\
(0.020)\end{array}$ & $\begin{array}{c}0.019 \\
(0.034)\end{array}$ \\
\hline $50^{\text {th }}-10^{\text {th }}$ gap & $\begin{array}{c}0.027 \\
(0.125)\end{array}$ & $\begin{array}{l}-0.105 \\
(0.218)\end{array}$ & $\begin{array}{c}0.160 \\
(0.143)\end{array}$ & $\begin{array}{c}0.212 \\
(0.159)\end{array}$ \\
\hline $90^{\text {th }}-10^{\text {th }}$ gap & $\begin{array}{c}0.064 \\
(0.179)\end{array}$ & $\begin{array}{l}-0.022 \\
(0.317)\end{array}$ & $\begin{array}{c}0.151 \\
(0.227)\end{array}$ & $\begin{array}{c}0.168 \\
(0.257)\end{array}$ \\
\hline \multicolumn{5}{|c|}{$\begin{array}{l}\text { (b) Intra-establishment residual } \\
\text { inequality: }\end{array}$} \\
\hline$\sigma_{j t}$ & $\begin{array}{l}0.019 * * * \\
(0.006)\end{array}$ & $\begin{array}{l}0.017^{* *} \\
(0.008)\end{array}$ & $\begin{array}{l}0.022^{* *} \\
(0.010)\end{array}$ & $\begin{array}{c}0.010 \\
(0.016)\end{array}$ \\
\hline $50^{\text {th }}-10^{\text {th }}$ gap & $\begin{array}{l}0.018^{* * *} \\
(0.006)\end{array}$ & $\begin{array}{c}0.012 \\
(0.009) \\
\end{array}$ & $\begin{array}{c}0.003 \\
(0.016)\end{array}$ & $\begin{array}{c}0.026 \\
(0.022) \\
\end{array}$ \\
\hline $90^{\text {th }}-10^{\text {th }}$ gap & $\begin{array}{l}0.031^{* * *} \\
(0.010)\end{array}$ & $\begin{array}{l}0.031^{* *} \\
(0.015) \\
\end{array}$ & $\begin{array}{c}0.026 \\
(0.023) \\
\end{array}$ & $\begin{array}{c}0.053 \\
(0.034) \\
\end{array}$ \\
\hline \multicolumn{5}{|c|}{$\begin{array}{l}\text { Number of establishments in the } \\
\text { estimation sample: }\end{array}$} \\
\hline Leavers & 515 & 212 & 129 & 69 \\
\hline Always members & 8,479 & 4,930 & 3,232 & 2,160 \\
\hline Off support (excluded) & 14 & 13 & 8 & 8 \\
\hline Total & 9,008 & 5,155 & 3,369 & 2,237 \\
\hline
\end{tabular}

Notes: $\sigma_{j t}$ is gives the intra-establishment residual inequality (see section III). The $90^{\text {th }}-10^{\text {th }}$ gap case implements model (9) in the text. Stata procedure "psmatch2" is used to calculate the radius matching estimates. ${ }^{* *},{ }^{* *}$, and ${ }^{*}$ denote significance at the $.01, .05$, and .10 levels, respectively. 
Table 7: Conditional difference-in-differences estimates of the effect of collective bargaining using collective agreement joiners vs. never members

\begin{tabular}{|c|c|c|c|c|}
\hline Parameter of interest & 1-year effect & 2-year effect & 3-year effect & 4-year effect \\
\hline \multicolumn{5}{|l|}{$\begin{array}{l}\text { a) Intra-establishment (log) } \\
\text { wage dispersion: }\end{array}$} \\
\hline Standard deviation & $\begin{array}{l}-0.001 \\
(0.011)\end{array}$ & $\begin{array}{c}0.010 \\
(0.021)\end{array}$ & $\begin{array}{l}-0.088^{*} \\
(0.037)\end{array}$ & $\begin{array}{l}-0.010 \\
(0.082)\end{array}$ \\
\hline $50^{\text {th }}-10^{\text {th }}$ gap & $\begin{array}{l}-0.051 \\
(0.101)\end{array}$ & $\begin{array}{c}0.080 \\
(0.192)\end{array}$ & $\begin{array}{l}-0.124 \\
(0.320) \\
\end{array}$ & $\begin{array}{l}-0.391 \\
(0.363)\end{array}$ \\
\hline $90^{\text {th }}-10^{\text {th }}$ gap & $\begin{array}{l}-0.088 \\
(0.170)\end{array}$ & $\begin{array}{c}0.187 \\
(0.307) \\
\end{array}$ & $\begin{array}{l}-0.139 \\
(0.508)\end{array}$ & $\begin{array}{l}-0.670 \\
(0.514)\end{array}$ \\
\hline \multicolumn{5}{|l|}{$\begin{array}{l}\text { b) Intra-establishment resid- } \\
\text { ual inequality: }\end{array}$} \\
\hline$\sigma_{j t}$ & $\begin{array}{c}0.000 \\
(0.005)\end{array}$ & $\begin{array}{c}0.003 \\
(0.011)\end{array}$ & $\begin{array}{l}-0.027 \\
(0.018)\end{array}$ & $\begin{array}{c}0.020 \\
(0.026)\end{array}$ \\
\hline $50^{\text {th }}-10^{\text {th }}$ gap & $\begin{array}{c}0.002 \\
(0.007) \\
\end{array}$ & $\begin{array}{c}0.007 \\
(0.012) \\
\end{array}$ & $\begin{array}{c}0.007 \\
(0.025) \\
\end{array}$ & $\begin{array}{c}0.023 \\
(0.040) \\
\end{array}$ \\
\hline $90^{\text {th }}-10^{\text {th }}$ gap & $\begin{array}{c}0.001 \\
(0.012) \\
\end{array}$ & $\begin{array}{l}0.005 \\
(0.019) \\
\end{array}$ & $\begin{array}{c}0.002 \\
(0.038) \\
\end{array}$ & $\begin{array}{c}0.035 \\
(0.055) \\
\end{array}$ \\
\hline \multicolumn{5}{|l|}{$\begin{array}{l}\text { Number of establishments in } \\
\text { the estimation sample: }\end{array}$} \\
\hline Joiners & 369 & 118 & 47 & 19 \\
\hline Never members & 3,872 & 2,199 & 1,304 & 773 \\
\hline Off support (excluded) & 28 & 20 & 22 & 25 \\
\hline Total & 4,269 & 2,337 & 1,373 & 817 \\
\hline
\end{tabular}

Note: See notes to Table 6. 
Figure 1: Wage inequality for the LIAB sample of full-time workers in establishments with at least 20 employees, western Germany,1996-2008

(a) Standard deviation of worker daily wages and intra-establishment residual inequality, $\sigma_{j t}$

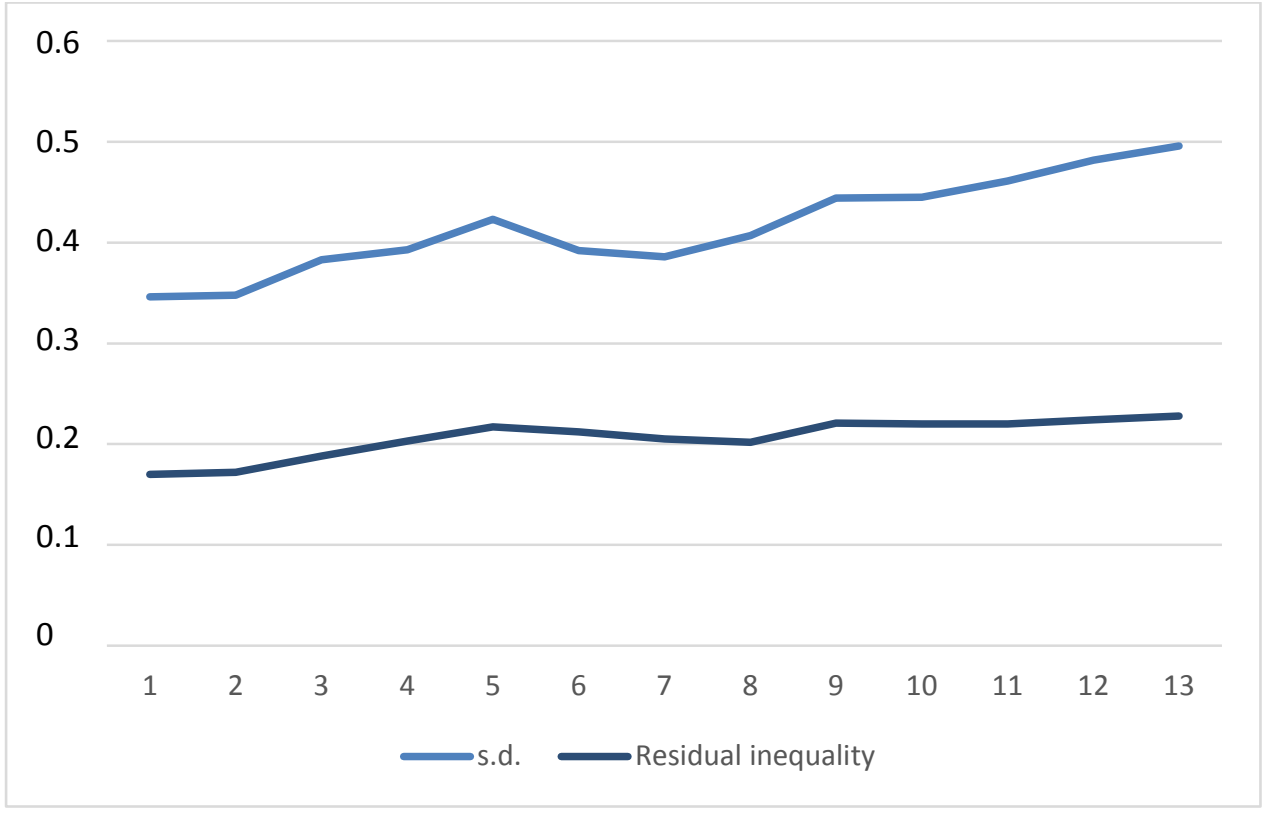

(b) $50^{\text {th }}-10^{\text {th }}$ and $90^{\text {th }}-10^{\text {th }}$ intra-establishment wage gaps and intra-establishment residual inequality, $\sigma_{j t}$

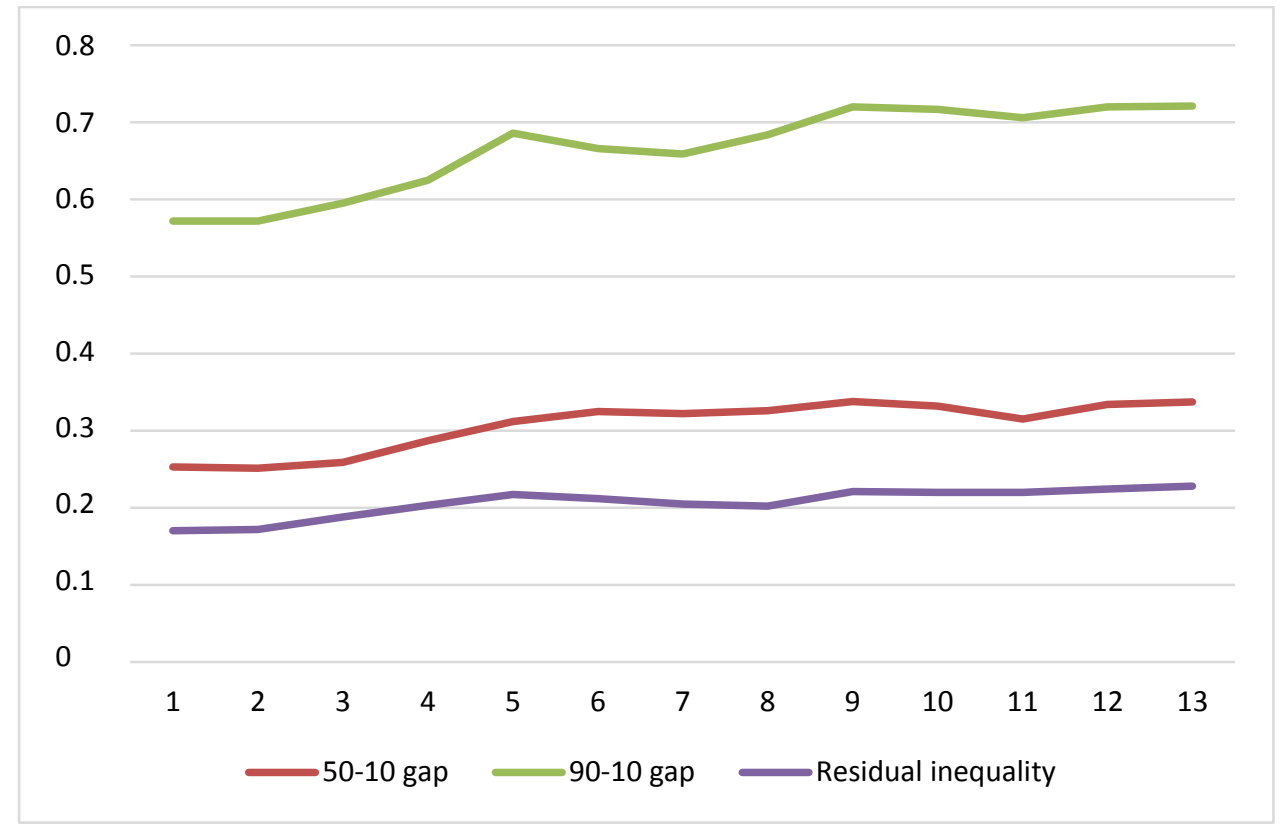


Appendix Table 1: Diagnostic statistics of the matched sample used in Table 6

\begin{tabular}{|l|c|c|c|c|c|}
\hline $\begin{array}{l}\text { Column in } \\
\text { Table 6 }\end{array}$ & Pseudo $\mathrm{R}^{2}$ & LR & P-value & Mean bias & Median bias \\
\hline First & 0.001 & 0.86 & 1.000 & 1.2 & 0.9 \\
\hline Second & 0.002 & 1.27 & 0.999 & 2.6 & 1.6 \\
\hline Third & 0.004 & 1.27 & 0.999 & 3.8 & 4.3 \\
\hline Fourth & 0.010 & 1.98 & 0.992 & 5.6 & 4.2 \\
\hline
\end{tabular}

Notes: The pseudo-R2 and likelihood ratio (LR) statistics are drawn from the propensity score regression (probit) run after matching the treated and untreated groups. The likelihood ratio tests the joint significance of all included variables in the probit regression. The mean and median bias are summary indicators of the distribution of the absolute value of the bias.

Appendix Table 2: Diagnostic statistics of the matched sample used in Table 7

\begin{tabular}{|l|c|c|c|c|c|}
\hline $\begin{array}{l}\text { Column in } \\
\text { Table 7 }\end{array}$ & Pseudo R & LR & P-value & Mean bias & Median bias \\
\hline First & 0.001 & 0.65 & 1.000 & 2.0 & 1.5 \\
\hline Second & 0.005 & 1.55 & 0.997 & 4.1 & 3.6 \\
\hline Third & 0.034 & 4.44 & 0.880 & 12.6 & 9.0 \\
\hline Fourth & 0.055 & 2.92 & 0.968 & 15.4 & 12.3 \\
\hline
\end{tabular}

Note: See notes to Appendix Table 1. 